\title{
Menopause Does Not Reduce Hematoma Risk After Reduction Mammoplasty Surgery: A Retrospective Analysis
}

\section{Menopoz Meme Küçültme Ameliyatı Sonrası Hematom Riskini Azaltmaz; Retrospektif Analiz}

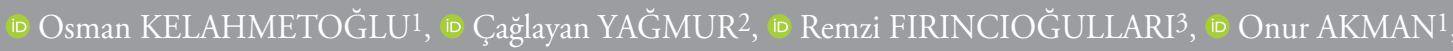 \\ iD Ethem GÜNEREN1 \\ Bezmialem Vakıf University Faculty of Medicine, Department of Plastic, Reconstructive and Aesthetic Surgery, İstanbul, Turkey \\ 2 Private Practic, Samsun, Turkey \\ 3 Private Can Hospital, Clinic of Plastic Cerrahi Surgical, İzmir, Turkey
}

\begin{abstract}
Objective: Hematoma is one of the early complications of breast reduction surgery. According to our literature review, this concomitance was not discussed in detail. The aim of this study is to show the relationship of postoperative hematoma with menopausal status in reduction mammoplasty patients.

Methods: This study included 153 patients who underwent breast reduction surgery from 2014 to 2018, and had no comorbid disease and were questioned for menopause retrospectively. The patients were divided into two groups: Group 1 comprised premenopausal women, and Group 2 comprised postmenopausal women.

Results: The mean age of the patients in Group 1 and Group 2 was $33.26 \pm 7.58$ years and $52.96 \pm 4.34$ years, respectively $(\mathrm{p}=0.00)$. The mean of total resected tissue weights in Groups 1 and 2 were $2.104 \pm 1.201$ grammes and $2.492 \pm 1.098$ grammes, respectively $(\mathrm{p}=0.119)$. Hematomas were seen in six $(4.8 \%)$ patients in Group 1 , and no hematoma was seen in Group $2(\mathrm{p}=0.593)$.
\end{abstract}

Conclusion: Our findings showed that menopause does not reduce the risk for hematoma, but we recommend further clinical studies.

Keywords: Breast reduction, hematoma, menopause

\section{ÖZ}

Amaç: Hematom, meme küçültme cerrahisinin erken komplikasyonlarından biridir. Literatür taramamıza göre birlikteliğini sorgulayan detaylı bir çalışmaya rastlamadık. Bu çalışmanın amacı meme küçültme ameliyatı geçirmiş hastalarda menopozal durum ile hematom ilişkisini göstermeye çalışmaktır.

Yöntemler:Bu çalışmaya, 2014-2018 yılları arasında meme küçültme cerrahisi geçiren, eşlik eden hastalığı olmayan ve menopoz için sorgulanmış 153 hasta dahil edildi. Hastalar; premenopozal ve postmenopozal olarak 2 gruba ayrıldılar.

Bulgular:Grup 1 ve Grup 2'deki hastaların yaş ortalaması sırasıyla $33.26 \pm 7.58$ ve $52.96 \pm 4.34 \mathrm{idi}(\mathrm{p}=0,00)$. Grup 1 ve Grup 2'de çıkartılan ortalama doku miktarları sırasıyla $2.104 \pm 1.201$ gram ve $2.492 \pm 1.098$ gram ( $\mathrm{p}=0,119)$. Grup 1'de 6 hastada hematom görüldü $(\% 4,8)$ ve Grup 2'de hiçbir hastada hematom görülmedi( $\mathrm{p}=0,593)$.

Sonuç:Sonuçlarımız göstermiştir ki: menopoz, hematoma riskini düşürmez fakat daha geniş serili klinik çalışmaların yapılmasını öneririz.

Anahtar Sözcükler: Meme küçültme, hematom, menopoz
Address for Correspondence: Osman KELAHMETOĞLU, Bezmialem Vakıf University Faculty of Medicine, Department of Plastic, Reconstructive and Aesthetic Surgery, İstanbul, Turkey

E-mail: osmankelahmetoglu@gmail.com ORCID ID: orcid.org/0000-0002-6651-2872

Cite this article as: Kelahmetoğlu O, Yağmur Ç, Fırıncıoğulları R, Akman O, Güneren E. Menopause Does Not Reduce Hematoma Risk After Reduction Mammoplasty Surgery: A Retrospective Analysis. Bezmialem Science 2020;8(4):379-382. 


\section{Introduction}

Reduction mammoplasty is one of the most common procedures performed around the world with the highest patient satisfaction rates. Contrary to common belief, it is not only an aesthetic operation, but also a reconstructive procedure, since most patients have been referred for relief of symptoms due to macromastia, such as neck and back pain, shoulder grooving, intertrigo and poor self-image $(1,2)$. Breast reduction surgery is a complex procedure. It involves adjusting tissue, respecting the pedicle and controlling the bleeding that requires extraordinary attention since wound healing problems are common $(3,4)$.

Breast reduction at older ages is more demanding according to several aspects of vital differences in surgical practice, i.e. diminished metabolism and reduced immune defence mechanisms and slowed wound healing. In addition, major hormonal changes occur during menopause that affect breast tissue as well (5). At older ages, adipose tissue replaces breast glandular tissue due to decreased vascularity and hormonal inactivity. The cumulative effects of these adverse reactions compromise flap surgery $(3,4,6-8)$. Early surgery-related complications are hematoma, seroma, skin loss, wound separation, cellulitis and nipple-areola ischaemia (2). Late wound healing dependent complications are scar deformities, unfavourable scars, loss of shape and fat necrosis (2).

Hematoma is one of the early and devastating complications of breast reduction surgery. It is neither a simple, early surgery nor a complex late wound-related complication since it generally requires evacuation in revisional surgeries. If it is not treated correctly and timely, it can not only delay wound healing but also serious infection with increased intramural pressure tissue necrosis and loss of tissue are common.

In this study, we plan to show the relationship between postoperative hematoma and menopausal status in patients who had reduction mammoplasty. Although it is widely accepted that blood supply to the breasts is expected to decrease in postmenopausal patients, no study has inspected the difference in the incidence of hematoma in breast reduction surgery between premenopausal and postmenopausal women in a statistical and scientific manner. We aimed to put forward a definitive and statistical study to find whether this difference exists. According to our literature review, this concomitance was not discussed in detail.

\section{Method}

This study retrospectively reviewed 185 consecutive patients who underwent breast reduction surgery from 2014 to 2018 . Patients with comorbid disease and hormone replacement therapy were excluded. This study included 153 patients who had no comorbid disease and were questioned about menopause. The patients were divided into two groups as Group 1 was premenopausal, and Group 2 was postmenopausal women, respectively. Demographic data, such as menopausal status, age, total resection weight (in grammes) and hematoma complication count, were obtained from medical records.

All patients were assessed preoperatively for breast pathology by ultrasonography, and those $>40$ years of age underwent breast mammography.

This article does not contain any studies with human or animal subjects.

\section{Statistical Analysis}

An independent samples test was performed to compare age and total resection weight. Complication data were then analysed using Fisher's exact test. All calculations were done with SPSS for Windows 16 (SPSS, Inc., Chicago, Ill.).

A p-value of less than 0.05 indicated statistical significance.

\section{Results}

Demographic data for the two groups are summarised in Table 1. The mean age of the patients in Group 1 and Group 2 was $33.26 \pm 7.58$ years and $52.96 \pm 4.34$ years, respectively. As expected, there was a significant difference between the two groups $(\mathrm{p}=0.00)$. The mean of total resected tissue weights in Groups 1 and 2 were $2.104 \pm 1.201$ grammes and $2492 \pm 1098$ grammes, respectively. Regarding the total resection weight, there were no significant differences between the two groups $(\mathrm{p}=0.119)$. Hematomas were seen in six (4.8\%) patients in Group 1 and drained in the operating room. No hematoma was seen in Group 2. However, there was no statistical difference between Group 1 and Group 2 in the rate of hematoma ( $\mathrm{p}=0.593)$.

\section{Discussion}

Reduction mammoplasty is a common surgical procedure. The aims of this surgery are the correction of breast aesthetically and relief of physical problems due to macromastia (2-9). This surgery

Table 1. Patient demographic data showing the number of patients, age, total resection weight and the rate of hematoma

\begin{tabular}{|c|c|c|c|}
\hline & Group 1 & Group 2 & $p$ \\
\hline Number of patients & 125 & 28 & \\
\hline Age (years) & $33.26 \pm 7.58$ & $52.96 \pm 4.34$ & 0.00 * \\
\hline Rate of hematoma (\%) & 4.8 & 0 & 0.593 \\
\hline
\end{tabular}


may be associated with bleeding and blood loss (10). Hematoma is one of the acute complications. It needs an urgent operation to stop the bleeding of vessels and to drain. To avoid this complication, it is recommended that haemostasis is performed under normotensive and bleeding perioperative is checked under hypertensive anaesthesia (3). In our case series, we performed all surgeries under normotensive anaesthesia and before closing incisions, we checked bleeding under perioperative hypertensive anaesthesia. In this study, the patients who had hematoma underwent a secondary operation to evacuate it. According to the BRAVO study results, the incidence of hematoma was 3.7\% (4). In a large case series, hematoma incidence was $0.82 \%$ (6). A different study reported hematoma complications as $4.1 \%$ and $6 \%$ overall and larger than 1.000 gramme per breast, respectively (7). Chun et al. (8) found the hematoma rate as $1 \%$. In the current study, the overall hematoma incidence was $3.9 \%$; in the premenopausal group, the hematoma rate was $4.8 \%$. These results were similar to those in the literature.

Menopause is the permanent absence of menstrual periods (11). In the postmenopausal period, oestrogen levels decrease and the loss of oestrogen causes some structural changes in breast tissue (11). It was shown that menopause caused fibroglandular tissue to decrease in breast magnetic resonance imaging (12). In a different study, age and menopause affect dense breasts changing them into nondense breasts. Nondense breasts have less glucose uptake than dense breasts (13). Thus, this decrease indicates a reduction in vascularity.

In the current work, all hematomas were seen in premenopausal patients. There was no significant difference between Groups 1 and 2. If we had a significant difference between Groups 1 and 2 , this result would have been thought of as a technical fault in the premenopausal group.

The incidence of hematoma reported in the literature varies between $1 \%$ and $6 \%$. The hematoma rate in our study is $3.9 \%$ for all patients, $4.8 \%$ in premenopausal and $0 \%$ in postmenopausal patients. Even though, the weakness our study was the unequal number of patients between groups might have caused the statistical insignificance between hematomas incidents, the higher hematoma incidence in premenopausal women could have been due to surgical error in the study.

On the other hand, age is another difference between the premenopausal and postmenopausal groups. Nelson et al. have found that age was not a significant risk factor for early complications after breast reduction surgery (14). The current work also has similar results.

\section{Conclusion}

The weakness of this study was that the number of cases in the groups was not equal. Although we have found that menopausal status does not reduce the risk for hematoma after breast reduction surgery, we advise that additional clinical studies, including larger numbers of patients, be conducted to clarify and resolve this issue accurately.

\section{Ethics}

Ethics Committee Approval: This study retrospectively reviewed.

Informed Consent: All participants signed an informed consent agreement.

Peer-review: Externally and internally peer reviewed.

\section{Authorship Contributions}

Surgical and Medical Practices: O.K., Concept: O.K., Ç.Y., E.G., Design: O.K., Ç.Y., E.G., Data Collection or Processing: O.K., Ç.Y., R.F., O.A., Analysis or Interpretation: O.K., Ç.Y., R.F., O.A., E.G., Literature Search: O.K., Ç.Y., R.F., O.A., E.G., Writing: O.K., Ç.Y., O.A.

Conflict of Interest: No conflict of interest was declared by the authors.

Financial Disclosure: The authors declared that this study received no financial support.

\section{Acknowledgements}

The authors would like to thank Sedat Ziyade M.D. for assistance with the statistical analysis.

\section{References}

1. Lopez MM, Castillo AC, Kaltwasser K, Phillips LG, Moliver CL. Surgical Timing and the Menstrual Cycle Affect Wound Healing in Young Breast Reduction Patients. Plast Reconstr Surg 2016;137:40610.

2. Cabral IV, da Silva Garcia E, Sobrinho RN, Pinto NLL, Juliano Y, Veiga-Filho J, et al. Use of the BREAST-Q ${ }^{\mathrm{TM}}$ Survey in the Prospective Evaluation of Reduction Mammaplasty Outcomes. Aesthetic Plast Surg 2018;42:388-95.

3. Shestak KC, Davidson EH. Assessing Risk and Avoiding Complications in Breast Reduction.

4. Clin Plast Surg 2016;43:323-31.

5. Cunningham BL, Gear AJ, Kerrigan CL, Collins ED. Analysis of breast reduction complications derived from the BRAVO study. Plast Reconstr Surg 2005;115:1597-604.

6. Shermak MA, Chang D, Buretta K, Mithani S, Mallalieu J, Manahan $\mathrm{M}$. Increasing age impairs outcomes in breast reduction surgery. Plast Reconstr Surg 2011;128:1182-7.

7. Gupta V, Yeslev M, Winocour J, Bamba R, Rodriguez-Feo C, Grotting JC, et al. Aesthetic Breast Surgery and Concomitant Procedures: Incidence and Risk Factors for Major Complications in 73,608 Cases. Aesthet Surg J 2017;37:515-27.

8. O'Grady KF, Thoma A, Dal Cin A. A comparison of complication rates in large and small inferior pedicle reduction mammaplasty. Plast Reconstr Surg 2005;115:736-42.

9. Chun YS, Schwartz MA, Gu X, Lipsitz SR, Carty MJ. Body mass index as a predictor of postoperative complications in reduction mammaplasty. Plast Reconstr Surg 2012;129:228e-33e.

10. Cogliandro A, Barone M, Cassotta G, Tenna S, Cagli B, Persichetti P. Patient Satisfaction and Clinical Outcomes Following 414 Breast 
Reductions: Application of BREAST-Q. Aesthetic Plast Surg 2017;41:245-9.

11. Sariguney Y, Demirtas Y, Findikcioglu F, Ayhan S, Latifoglu O, Cenetoglu $S$, et al. Proper timing of breast reduction during the menstrual cycle. Ann Plast Surg 2004;53:528-31.

12. Monteleone P, Mascagni G, Giannini A, Genazzani AR, Simoncini T. Symptoms of menopause - global prevalence, physiology and implications. Nat Rev Endocrinol 2018;14:199-215.

13. King V, Gu Y, Kaplan JB, Brooks JD, Pike MC, Morris EA. Impact of menopausal status on background parenchymal enhancement and fibroglandular tissue on breast MRI. Eur Radiol 2012;22:2641-7.
14. Mavi A, Cermik TF, Urhan M, Puskulcu H, Basu S, Cucchiara AJ, et al. The effect of age, menopausal state, and breast density on (18) F-FDG uptake in normal glandular breast tissue. J Nucl Med 2010;51:347-52.

15. Nelson JA, Fischer JP, Wink JD, Kovach SJ 3rd. A populationlevel analysis of bilateral breast reduction: does age affect early complications? Aesthet Surg J 2014;34:409-16. 